\title{
Interfaces
}

INTERFACES Image Texte Language

$43 \mid 2020$

Création/Destruction

\section{Susan Minot - writer and artist}

\section{Donald Friedman}

\section{(2) OpenEdition}

\section{Journals}

Electronic version

URL: http://journals.openedition.org/interfaces/901

DOI: 10.4000/interfaces.901

ISSN: 2647-6754

\section{Publisher:}

Université de Bourgogne, Université de Paris, College of the Holy Cross

\section{Printed version}

Date of publication: 15 July 2020

Number of pages: $153-156$

ISSN: 1164-6225

\section{Electronic reference}

Donald Friedman, « Susan Minot - writer and artist », Interfaces [Online], 43 | 2020, Online since 15 July 2020, connection on 31 December 2020. URL : http://journals.openedition.org/interfaces/901 ; DOl : https://doi.org/10.4000/interfaces.901

\section{(c) (†)}

Les contenus de la revue Interfaces sont mis à disposition selon les termes de la Licence Creative Commons Attribution 4.0 International. 


\title{
SUSAN MINOT - WRITER AND ARTIST
}

\author{
Donald Friedman
}

Donald Friedman interviewed Susan Minot in 2002. An edited excerpt of that interview may be viewed athttps://donaldfriedman.com/2019/05/I4/susan-minot-paints-everything-everywhere/. Below are an introduction to the interview and a full transcript of the excerpt.

\section{Introduction}

Susan Minot has drawn and painted throughout her life, and studied art briefly at Brown and Columbia Universities. She acquired the practice of making "little pictures, whether it was painting on old postcards I found, or snapshots I took or, if nothing else, doing watercolors at the tops of pieces of paper - usually while on the phone - which I'd then use for stationery." Both her writing and art began as private expressions, but her writing became "public and subject to judgment" and the way she earned her living, while "the drawing and painting became more of the private thing I was doing for no other reason than that I loved doing it."

In a 200I letter to me, as well as in the following interview, Minot emphasized she kept her art small - in cigarette-case-sized books at first - " to reinforce the idea that what I was doing was merely sketching, noting things down, doing studies. I was avoiding the intimidation of actually painting." Indeed, she eschews even the designations of "artist" or "writer"; "I like to say, 'I write,' or 'I paint,' and not 'I am an anything."'

Minot says she grew up in a family in which everyone always had something before them to do with their hands. It is a habit that has stayed with her throughout her life. Using her pocket-sized art materials, she records in paint whatever happens to be in front of her-whether it's a tree on the Masai Mara, friends, family, strangers on a boat, or the view from her hotel window. Sometimes the image accompanies a poem, or vice-versa; frequently it overlays and transforms a photograph or another printed image. 
The pictures, although practical as aides de memoire, are first of all a source of pleasure, a way, Minot says, of losing herself, of doing something that "doesn't have other expectations hanging over it... It is not the thing I am supposed to be doing. When I'm supposed to be doing something it tends to get my back up".

"I also find solace in painting because it's an alternative to writing. It doesn't involve words, and while it still requires the concentration that makes the time you are doing it disappear, it does not involve the mind the same way, or require logic in the same way. (Though of course painting has its own visual logic.) Painting allows me to convey something not from my head, but from my hand, through images. It may not be as specific - that is, it cannot express a precise notion in the way that words can, but an image can express so many other things — of mood and feeling and how people live and what the world looks like. Many of the watercolors I've done are notations of a place I'm passing through. I don't go searching for subjects, I paint what is in front of me."

Novelist, short story writer, poet, playwright, and screenwriter of Bertolucci's film Stealing Beauty (1995) and, with Michael Cunningham, Evening, (2007), Minot was born in Manchester, Massachusetts in 1956 , one of seven children in an upper-class family that includes a number of artists and writers. Her mother died in a car accident while Minot was in her senior year at Brown; upon graduation she went home to care for her father and younger sister. The experience inspired Minot's first stories which form part of her critically acclaimed first novel Monkeys (1986). Published in a dozen countries and winner of France's Prix Femina étranger, it details in a much-praised minimalist style the lives of seven children suffering with their father's alcoholism and their mother's death. Minot's stories have appeared in The New Yorker, Grand Street, Paris Review, and The Atlantic Monthly and have won O. Henry and Pushcart Prize awards. Minot received her M.F.A. from Columbia in I983. Her other works include Lust and Other Stories (1989), Folly (1993), Evening (1998), Rapture (2002), Poems 4 A.M. (2003) and Thirty Girls (20I4).

\section{Script of Susan Minot's interview - edited by filmmaker Michelle Memran}

https://donaldfriedman.com/2019/05/I4/susan-minot-paints-everything-everywhere/

\section{Pictures as habit}

I really like to say "I write", or "I paint”, and not "I am an—anything". 


\section{[Going through archived materials]}

...some xeroxes I used to color... Painting everything that's in front of me... You know, we were always kind of grew up doing things with our hands all the time — both my parents did — and I think with a lot of children around, my mother was always saying, "Come on, let us put the paints out and everyone do this." And I think once one of us started to do it, another one did it. ...here's one, That's my brother [displays painted on photo of brother] - Then I was doing these... paint on top of... [displays painted over printed stereoscopic card]. And here's a sort of semi-poem/drawing... $\mathrm{Me}$ - early years.

And then I started keeping these little books like this [flips through book of miniature paintings], and they were just sketches and I'd take them when I was going on trips usually-you know, while we were waiting for a flat tire to be fixed, I think, that's what was going on that day. I was in Kenya, in the Maasai Mara. This is...we were crossing in a boat at Lamu—- [these are the] people opposite me-[these are] stars at night. So these are all kind of records of, you know, my friends. And I have a very small little watercolor case that folds up like that, and you can just take it and it doesn't take up much room.

And then I started just a little bit bigger size when I take a trip, so these are... just developed a format of kind of... like a television-edged [displays picture with white margins between page edge and image] you know-

[Interrupted by Baby Ava: Hang on, a sec. I'm here-just take this for a second and I'll give you a little bit of the bottle. Okay, Okay. Oh, that won't do.]

\section{Images for words}

You know in all of these, almost always the date is there, and there's... the place that I did the picture is there, because that's all important for a, you know, the record of it. So that each little picture is a little story that I could say more about, but kind of relieved to NOT have to say anything more about it. It's just in images, it's, it's not in words, which I usually belabor.

I mean, I think, with my books, they are guided by an image, like I'll see a situation, a visual situation that will resonate for some reason, and that's usually at the heart of my ideas for a story or something that I want to write, and in the writing of it I have to describe how it looks to me. It's more about... that to me is the most important thing to convey: how it looks. 


\section{Narration}

Our dreams are - they are not about music and they are not about words - there may be some about dialogue, but they are, you know, ninety percent images. And it's the way our psyches work out our, you know, frustrations or our desires.

[Showing scratched photos]

This is crossing the Serengeti. It is again I999, Loliondo, Tanzania. This is a fire at night, so this is like another version of the watercolors that are... you know, I can snap something, so that's like ink, and scratched. And here again my sort of narration: "I held his head in my hands till it was over."

What kind of camera were you using?

My little —-where is it? - I'll take a picture of you. 